\title{
Program Air Siap Minum Untuk Siswa dan Penduduk Terdampak Gempa di Sekolah Dasar Nengeri 3 Malaka Teluk Nara Pemenang, Kabupaten Lombok Utara
}

\author{
Made Sutha Yadnya*1, Ahmad Tahmid², Abdulah Zainuddin ${ }^{3}$, Bulkis Kanata ${ }^{4}$, \\ Teti Zubaidah ${ }^{5}$, Paniran ${ }^{6}$ \\ ${ }^{1}$ Electrical Enginnering, PUI Geomagnetic Laboratory, the University of Mataram, Lombok, Indonesia. \\ ${ }^{13465}$ Jurusan Teknik Elektro, Fakultas Teknik Universitas Mataram, NTB, Indonesia \\ ${ }^{2}$ Xylem Inc, Indonesia
}

\section{Article history}

Received: 28 Januari 2020

Revised: 18 Februari 2020

Accepted: 23 Maret 2020

*Corresponding Author:

Made Sutha Yadnya

Jurusan Teknik Elektro,

Fakultas Teknik Universitas

Mataram, NTB, Indonesia

Email: msyadnya@unram.ac.id

Abstract: Since the magnitude 7 magnitude earthquake occurred in August 2018, Lombok Island, especially North Lombok Regency, has been severely affected by infrastructure damage. From the data available, there are very few sources of clean water and are scarce. For this reason, in March 2019 the University of Mataram Community Service Team was represented by PUI Geomagnetic together with the largest water pump company in the world, Xylem Inc. installed a water pump at SDN 3 Teluk Nara Pemenang. The result of pumping water is clean water ready to drink.

Keywords: earthquake; pump; clean water

Abtrak: Sejak terjadinya gempa besar yang berkekuatan magnetudo 7 SR bualn Agustus 2018, Pulau Lombok khususnya Kabupaten Lombok Utara sangat terdampak terhadap kerusakan infrastuktur. Dari data yang tersedia bahwa sumber air bersih di beberapa tempat sangat sedikit dan cenderung langka. Untuk itu pada Maret 2019 Tim Pengabdian Masyarakat Universitas Mataram diwakili PUI Geomagnetik bersama perusahan pompa air terbesar di dunia yaitu Xylem Inc. memasang pompa air di SDN 3 Teluk Nara Pemenang. Hasil pemompaan air tersebut adalah air bersih yang siap diminum.

Kata Kunci: gempa, pompa, air bersih

\section{PENDAHULUAN}

Xylem Inc. adalah salah satu penyedia teknologi penyulingan air global terbesar di dunia, memungkinkan pelanggan untuk memompa, mengolah, mengetes dan secara efisien menggunakan air di dalam fasilitas mengeloaan air, perumahan, gedung komersial, pertanian dan industri. Xylem Inc beroperasi di lebih dari 150 negara. Diluncurkan pada 2011 dari spin-off bisnis yang berhubungan dengan air dari ITT Corporation, Xylem berkantor pusat di White Plains, NY. Di Indonesia penyalur utama adalah INTERNUSA untuk melihat bisa lebih fokus pengembangan serta potensi air di Indinesia. Perusahan Xylem Inc. ini dengan dana CSR memberikan batuan pemasangan pompa di Kabupaten Lombok Utara sejak 2017 sudah sebanyak empat titik sebelum gempa, dan dua titik direncanakan sesudah gempa. Pemberiian pompa air sebelum gempa adalah untuk sanitasi agar air tersebut dapat langsung ke masayarakat menggunakan enam filter. Namun setelah gempa air yang didapatkan sudah bisa langsung dikonsumsi dengan menggunakan 10 filter (Xylem 2018). 
Badan Nasional Penanggulangan Bencana atau BNPB telah merampungkan validasi dampak gempa Lombok, Nusa Tenggara Barat, sepanjang Agustus 2018. Dari data per 10 September 2018 ini, telah diketahui berapa banyak korban jiwa, rumah yang hancur, fasilitas publik yang rusak, hingga kebutuhan dana untuk merehabilitasi dan merekonstruksi seluruh dampak tersebut. Korban jiwa di kabupaten Lombok Utara adalah 564 orang, 82,8\% dari seluruh korban meninggal atau sekitar 467 jiwa ada di Lombok Utara, korban luka mencapai 1.584 jiwa dimana 829 orang atau 52,3\% berasal dari Lombok Utara. Infrastruktur seperti rumah rusak mencapai 167 unit dan 33,3 \% Lombok Utara menjadi lokasi pengungsi terbesar. Infrastruktur penunjang secara total, BNPB mencatat ada 214 infrastruktur seperti jembatan, jalan, terminal bus, dermaga, irigasi hingga bendungan yang rusakdan terdampak bencana. Kerusakan terbanyak dialami oleh jaringan irigasi sebesar $45 \%$ atau 97 unit, lalu jalan $28 \%$ atau 61 unit, SPAM (Sistem Penyediaan Air Minum) dan IPAL (Instalasi Pengolahan Air Limbah) sebesar $15 \%$ atau 32 unit. Secara akumulasi, kerusakan infrastruktur terbanyak terjadi di Lombok Utara dengan 85 unit. Sekolah rusak dan terdampak mencapai 1.194 unit dimana $53 \%$ atau sekitar 639 unit adalah bangunan Sekolah Dasar atau SD. Kemudian PAUD 254 unit, SMP 155 unit, SMA 72 unit, SMK 56 unit, dsn SLB 8 unit, kerusakan fasilitas pendidikan terbanyak terjadi kembali terjadi Lombok Utara dengan 294 unit sekolah, Fasilitas kesehatan Gempa ini menyebabkan 321 fasilitas kesehatan rusak dengan 26,48 \% di antaranya berada di Lombok Barat. Sementara 35,85 \% atau sebanyak 115 unit dialami oleh Pos Kesehatan Desa atau Poskedes. Terdata ada 86 Puskesmas dan 9 rumah sakit. Rumah ibadah di NTB, terdapat 630 unit Masjid rusak, 461 mushola, 1 gereja di Mataram, 1 Vihara, 50 pura, 267 masjid di Kabupaten Lombok Utara (BPBD, 2018).

Gempa dalam penelitian yang dilakukan oleh Pusat Unggulan Institusi (PUI) Geomagnetik memperoleh hubungan berkorelasi yang sangat kuat dengan flux magnet bumi. Magnet bumi yang mengalami pelemahan menyimpan energi potensial yang menyebabkan gempa. Pelemahan magnet bumi dapat dilihat dari perubahan (mengukur) Inklinasi dan Deklinasi posisi pengukuran dari kutub magnet bumi, untuk daerah Kabupaten Lombok Utara telah terjadi anomali sebelum terjadinya gempa. Penelitian tersebut membuktikan bahwa ada pengaruh magnet bumi untuk precursor gempa bumi. (Zubaidah, 2018).

Kebutuhan air bersih setelah gempa sangat kurang maka Pemerintah khusus Pemda NTB mengacu syarat air besih dari PP 32 tahun 2017. Penyediaan air oleh Pemda dapat dilakukan oleh penyedia secara gratis atau berbayar untuk masyarakat mengguanakan acuan sebagai dari "PERATURAN MENTERI KESEHATAN TENTANG STANDAR BAKU MUTU KESEHATAN LINGKUNGAN DAN PERSYARATAN KESEHATAN AIR UNTUK KEPERLUAN HIGIENE SANITASI, KOLAM RENANG, SOLUS PER AQUA, DAN PEMANDIAN UMUM”. Dengan pasalpasal sebagai berikut: Pasal 1 Dalam Peraturan Menteri ini yang dimaksud dengan: 1). Standar Baku Mutu Kesehatan Lingkungan adalah spesifikasi teknis atau nilai yang dibakukan pada media lingkungan yang berhubungan atau berdampak langsung terhadap kesehatan masyarakat, 2). Persyaratan Kesehatan adalah kriteria dan ketentuan teknis kesehatan pada media lingkungan, 3). Air untuk Keperluan Higiene Sanitasi adalah air dengan kualitas tertentu yang digunakan untuk keperluan sehari-hari yang kualitasnya berbeda dengan kualitas air minum (Menteri Kesehatan RI, 2017).

Kekurangan air bersih di daerah terdampak gempa merupakan kendala yang harus segera diatasi. Program air siap minum untuk kondisi daerah terdampak gempa harus terpenuhi. Adapun salah satu pola untuk mengatasinya adalah: 1). Dengan memasang pompa untuk menaikan air tanah, 2). Air tanah diproses untuk mendapatkan air bersih (kalau bisa langsung dapat di minum), 3 ). Tanggki untuk menyimpan air yang diletakkan tiga meter dari posisi tempat pengambilan air (kran 
pengatur air). . Kondisi awal sebelum program air siap minum daerah Malaka di Teluk Nara sangat membutuhkan air bersih, sekolah SDN 3 hampir rata dengan tahah, di awal tahun 2019 terlah dilakukan pendirian ulang sekolah dengan infrastuktur masih kurang, apalagi air bersih belum mencukupi. Dari posisi lokasi air yang ada adalah air payao dan air berlumpur ini kurang sehat. Hal ini sangat tepat dilaksanakan program pengabdian di SDN 3 Malaka Teluk Nara.

\section{METODE}

Instalasi air sekala rumahan (sekolah) menjadi salah satu faktor penting yang harus diperhatikan dalam suatu areal bagunan. Membuat instalasi pompa itu, tentunya ada beberapa hal yang harus menjadi pertimbangkan sebelum memilih untuk membangun instalasi pompa sendiri. Hal-hal penting tersebut di antaranya:

1. Pastikan kelancaran pasokan air tanah di lingkungan SDN 3 Teluk Nara, kondisi tanah yang stabil dan pasokan air di musim hujan maupun di musim kemarau.

2. Pastikan kualitas air tanah di lingkungan tempat bebas dari aliran limbah, tidak berbau atau keruh.

3. Sediakan tempat untuk menaruh bak penampung atau tangki. Memang tidak harus menggunakan tangki higienis, namun untuk hemat listrik, mesin yang lebih awet dan mengantisipasi listrik disediakan disel (generator solar), maka disarankan untuk memasang tangki air di rumah.

Jika lokasi terletak di komplek sekolah dengan luas tanah yang terbatas, ruang garasi mobil dekat pagar bisa menjadi pilihan yang baik untuk menggali sumber air. Ruang pemasangan pompa tersedia area terbuka adalah ruang terbuka, itu akan menjadi pilihan yang lebih baik lagi. Terdapat hal lain yang juga perlu pertimbangkan beberapa ketentuan dengan acuan serta aturan sebagai berikut diantaranya:

1. Jarak antara sumur dengan tangki air, jarak yang semakin dekat, maka semakin baik.

2. Jarak antara sumur dengan rencana posisi mesin jet pump, semakin dekat maka semakin bagus.

3. Ada keleluasaan untuk mengeluarkan pipa dari dalam sumur meskipun dengan posisi miring.

Hal lain yang perlu diperhatikan dalam hal ini adalah material-material yang digunakan, salah satunya pipa air. Sudah seharusnya memilih pipa dengan kualitas baik dan terpercaya (Rucika, 2016).

\section{HASIL DAN PEMBAHASAN}

Dalam memperingati Hari Air Sedunia khusus di Indonesia pada tanggal 22 Maret 2019 mengadakan pengabdian kepada masyakat terdampak gempa oleh Xylem Inc yang bergabung dengan Planet Water Foundations beserta volunteer dari Universitas Mataram saling bahu membahu untuk membangun pompa yang dilengkapi penyimpanan air (Tabung) dikenal AquaTower yang berlokasi di SD Negeri Malaka Teluk Nara, Kecamatan Pemenang, Kabupaten Lombok Utara, Nusa Tenggara Barat. Pelasanaan kegiatan ini bersamaan dengan pelaksanaan kegiatan serupa di empat negara pada tahun ini untuk \# Project24. Sukarelawan yang terlibat berbaur dengan para siswa dengan cemas menunggu untuk minum air bersih pertama mereka, air yang dihasilkan dari penyulingan adalah air yang dapat diminum langsung, karena sudah difilter sampai 6 filter pemisah air dari air tanah menjadi air minerial siap saji. Kegiatan yang dilaksanakan tidak hanya aksi pemasangan tower tapi aksi 
kalaborasi untuk menghilangkan trauma gempa di Lombok Utara. Pembelajaran tentang AirKesehatan \& Kebersihan melalui program berbasis aktivitas langsung pada sekolah oleh sukarelawan dari Xylem, Planet Water, serta Universitas Mataram. Dalam pelaksanaan di SDN 3 Malaka Teluk Nara dihadiri oleh Muspida Kecamatan Pemenang, seluruh murid, guru-guru, serta yang terkait. Untuk penyelenggara acara sangat dibantu oleh staf Global Water. Kegiatan ini bertepatan dengan hari Air Sedunia tanggal 22 Maret 2019. Hari Air Sedunia merupakan hari pemanfaatan air untuk belajar bagi semua pihak sangat tepat hal ini dilaksanakan pengabdian terhadap masyarakat.

Pada saat dilaksanakan pengabdian seluruh komponen terkait melaksasanakan dengan antusias terbukti dalam kurun waktu 4 jam dapat diselesaikan air siap minum sudah ada ditangan dan sudah terbukti bisa diminum. Hasil dari proses ini juga sudah ditest dengan beberapa pengukuran serta lebih lanjut diuji di labiratorium dinyatakan layak untuk diminum.

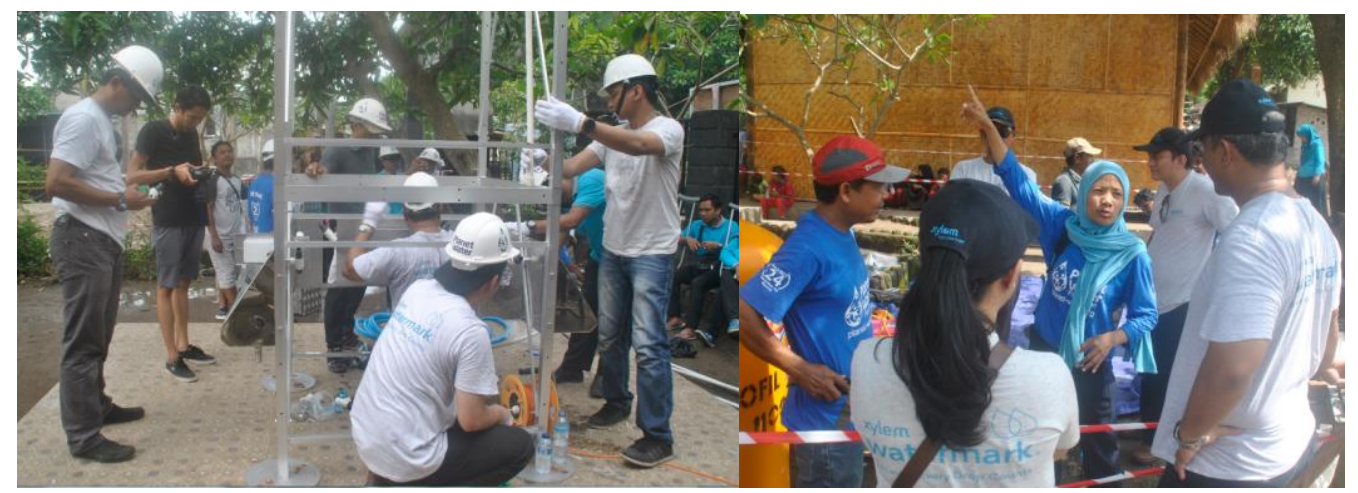

Gambar 1 Pemasangan rangka pompa dan sosialisasi siswa dan penduduk

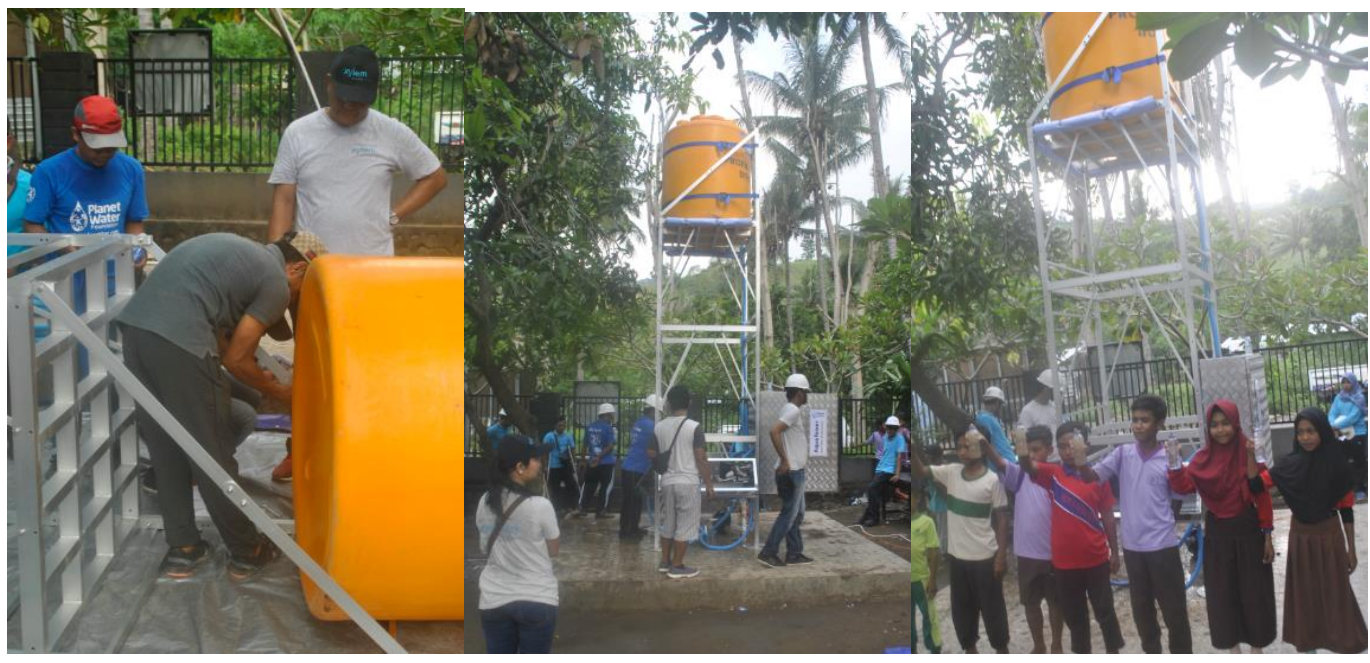

Gambar 2 Pemasangan pompa, menjelaskan fungsi, dan anak SDN 3 langsung konsumsi air.

Pengabdian dimulai dari persiapan kegiatan baik aspek administrasi, lokasi, dan peralatan dengan melibatkan Xylem, Planet Water, dan PUI Universitas Mataram. Secara rinsi, persiapan tersebut adalah menghubungi SDN 3 Teluk Nara untuk pemasangan pompa, menyiapkan pompa, landasan berdirinya pompa, cara pemasangan pompa ini terlihat dari Gambar 1. Pada Gambar 2 
diperlihatkan pemasangan pompa mulai dari krangka penyangga drum pemyimpan air bersih setelah dipompa dari air tanah. Setelah pompa terpasang maka dilaksanakan sosialisasi penggunakan pompa tersebut dengan memberikan contoh langsung minum, penjelasan sanitasi, manfaat air untuk kehidupan serta lomba cerdas cermat seputar air bersih bagi kesehatan yang sehat.

Bagi siswa dan penduduk yang mendapatkan program ini sangat terbantu kebutuhan air minum sehari-hari. Program air siap minum ini sebagian besar merupakan penyaluran dana dari CSR Xylem Inc berkalaborasi dengan seluruh lapisan masyarakat. Dari pemasangan pompa dan tendon (tangki) sebenarnya mempunyai kapasitas kecil dibandingkan dengan kebutuhan penduduk sekitar, program ini hanya mampu memproduksi sekitar 8 drum atau lebih kurang 4000 liter air bersih. Penyediaan air siap minum masih terkendala dari catuan power listrik, karena pasokan listrik daerah gempa masih hidup mati bergiliran.

\section{KESIMPULAN DAN SARAN}

Kepedulian dunia usaha dan kalangan cendekiawan dapat bersatu untuk membatu masyarakat sebagai kepedulian dan penerapan hasil penelitian yang telah dilakukan. Khusus untuk program air bersih dilaksanakan di SDN 3 Malaka Teluk Nara para murid serta penduduk sekitarnya dapat memanfaatkan air untuk diminum secara langsung atau digunakan untuk memasak dan kebutuhan sehari-hari.

\section{Ucapan Terima Kasih}

Terima kasih diucapkan kepada Xylem Inc (Qaharuddin, Soleh Apip, Elena Siregar, Maulana), Global Water, yang telah memberikan dana dan personel, PUI Geomagnetik Dosen, Mahasiswa Jurusan Teknik Elektro Universitas Mataram, khusus Suci Raditya Yadnya (SMAN 1 Mataram) mendokumentasikan kegiatan, serta semua yang tidak disebutkan satu persatu dalam membantu dan menfasilitasi peyelesaian makalah ini. Pembiayaan untuk publikasi ini sepenuhnya menggunakan dana mandiri yang dikumpukan dari setoran setiap anggota Pengabdian pada Masyarakat. Semoga makalah ini dapat inspirassi dari kegiatan-kegiatan selanjutnya.

\section{DAFTAR PUSTAKA}

Xylem Inc, (2018), "https://www.xylem.com/en-us/products-services/pumps-packaged-pumpsystems/ "diakses tanggal 21 April 2019

Rucika, (2016) https://www.rucika.co.id/membangun-instalasi-pompa-air-di-rumah-simak-tips-ini diakses tanggal 28 April 2019

BPBD, (2018), "Laporan CNN Indonesia Selasa, 07/08/2018 18:59 WIB” Berita langsung diakses tanggal 24 April 2019

Menteri Kesehatan RI.,(2017) "PERATURAN MENTERI KESEHATAN REPUBLIK INDONESIA NOMOR 32 TAHUN 2017” diakses tanggal 26 April 2019

Zubaidah T., Kanata B.., Yadnya M.S., Riskia S., (2018) "Earth Magnetic Fields Evolution over Nusa Tenggara Region from Declination and Inclination Changes on Lombok Geomagnetic Observatory”. International Conference AEMT, IEEE Explore : 2018 2nd International Conference on Applied Electromagnetic Technology 